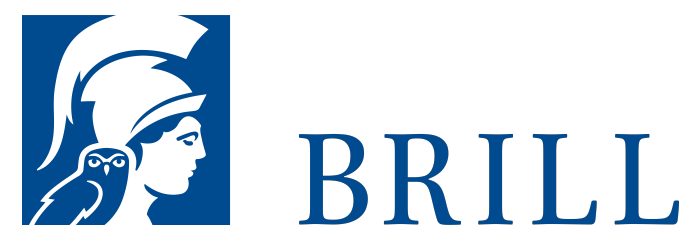

\title{
Eros and Revolution
}

The Critical Philosophy of Herbert Marcuse

Author: Javier Sethness Castro

In Eros and Revolution, Javier Sethness Castro presents a comprehensive intellectual and political biography of the world-renowned critical theorist Herbert Marcuse (1898-1979). Investigating the origins and development of Marcuse's dialectical approach vis-à-vis Hegel, Marx, Fourier, Heidegger, and Freud as well as the central figures of the Frankfurt School - Horkheimer, Adorno, Neumann, Fromm, and BenjaminSethness Castro chronicles the radical philosopher's lifelong activism in favor of anti-capitalism, anti-fascism, and antiauthoritarianism together with Marcuse's defiant revindication of global libertarian-socialist revolution as the precondition for the realization of reason, freedom, and human happiness.

Beyond examining Marcuse's revolutionary life and contributions, moreover, the author contemplates the philosopher's relevance to contemporary struggle, especially with regard to ecology, feminism, anarchism, and the general cause of worldwide social transformation.

Readership

All those interested in Critical Theory, Marxism, anarchism, social and political psychology, radical philosophy, existentialism, Romanticism, feminism, ecology, anti-militarism, and revolutionism: academic and public libraries, specialists, undergraduate and graduate students.

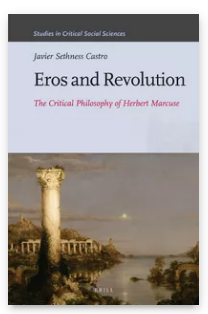

Pages: xi, $410 \mathrm{pp}$.

Language:

English

Subjects:

Critical Social

Sciences, Social

Sciences, Social

\& Political

Philosophy,

Philosophy,

Sociology \&

Anthropology,

Social Sciences,

Psychology,

Biology,

Intellectual

History, History

Publisher: Brill

Series:

Studies in

Critical Social

Sciences,

Volume: 86

E-Book (PDF)

Released online:

10 Jun 2016

ISBN: 978-90-

04-30870-1

List price

USD \$223.00

Hardback

Publication date: 16 Jun 2016 
Javier Sethness Castro, MSc. (2008), London School of 04-30869-5 List price Economics, is the author of Imperiled Life: Revolution against Climate Catastrophe (Institute for Anarchist Studies/AK Press, 2012) and For a Free Nature: Critical Theory, Social Ecology, and Post-Developmentalism (Lambert Academic Press, 2013). He contributed to Multidimensional Marcuse: Radical Thought/Action Today (Palgrave-MacMillan, forthcoming) and has participated in several International Herbert Marcuse Society conferences.

For more information see brill.com

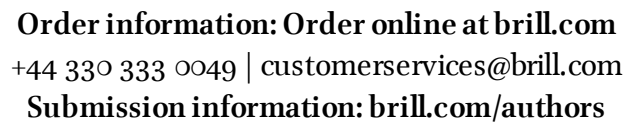

Titles published by Brill | Fink, Brill | mentis or Brill | Schöningh: +49(o)71 5413279216 | brill@brocom.de 